\title{
The Influence of Underground Storey to the Seismic Behaviour of Reinforced Concrete Buildings
}

\author{
Agim Seranaj $^{1}$, Luan Murtaj ${ }^{2}$, and Altin Seranaj ${ }^{3}$
}

\begin{abstract}
Taking into consideration that the dynamic and seismic response of the structures depends not only on the external action through the ground movements, but also on the characteristics of the structure itself, it is necessary to analyze structures with different possible cases. In many cases the ground floor is required to be different from the above floors, because of the usage as shops or other functionality and, the functionality requirements many times are the opposite to the structural requirements. With the above considerations and the conventional buildings in our country, in this paper is analyzed the influence of underground storey to the behaviour of reinforced concrete structure. Using the underground storey instead of ground storey as the transmitter between the ground and the structure makes the structural requirements easier to achieve and this can help the designer to fulfill the design criteria of their building structure. Different type of building structures are analyzed in different cases of underground storey involvement. The time history analysis is performed by SAP2000 software program. The structure is modeled in space using the finite element method. The El Centro earthquake is considered as the seismic action. The results of analysis show that the underground storey is influencing not only the period of vibrations, but also the internal member forces and base shear forces of the structures.
\end{abstract}

Keywords - reinforced concrete structures, underground storey, seismic response, time history analysis.

\section{INTRODUCTION}

$\mathrm{T}$ HE structural engineers always try to find solutions in order to improve the behaviour of the structures due to external actions. The structures can have different shapes in plan or elevation [3] [4]. In case of reinforced concrete buildings, besides the shape in plan, the elevation can have different situations. In many cases the ground floor is required to be different from the above floors, because of the usage as shops or other functionality. Based on the functionality, the first storey of these structures maybe required to have less stiffness then other storeys, tending to create soft storey structure [1] [2]. So, the requirements for the first storey are very complex and the functionality requirements are mostly the opposite to the structural requirements. Taking into account that the first storey is the one supporting the structure to the ground and transmitting the movements from ground to the

\footnotetext{
${ }^{1,2}$ Department of Structural Mechanics, Civil Engineering Faculty, Polytechnic University of Tirana

${ }^{3}$ Department of Building Construction and Transportation Infrastructure, Polytechnic University of Tirana, Albania
}

structure, the idea presented in this paper is to use the underground storey making these transmissions between the ground and the structure [5]. The functionality of underground floor makes the structural requirements easier than the ground floor and this can help the designer to fulfil the design criteria of their building structure. The possibility to use the underground structure can be considered in different structural solutions such as the involvement of surrounding reinforced concrete walls.

Taking into account the above considerations and the conventional buildings in our country, in the paper is analyzed the five storeys reinforced concrete structure. To study the effect of underground storey to the seismic behaviour of these buildings, three types of structures are considered: Type 1FRAME structure, Type 2-MIX structure and Type 3-BOX structure. These structures belong to the same building, but they differ to each other by their flexibility. Each type of structure is modelled in three different ways: First model of each type is the structure without underground storey; second model of each type is the structure with surrounding $\mathrm{RC}$ walls of underground storey and third model of each type is the structure with underground storey but the surrounding walls are not connected with the structure.

To calculate the dynamic parameters and to perform the seismic analyzes, the loads applied to the structure are: dead loads, live loads and earthquake loads [4]. The time history analysis are performed by SAP2000 software program [7]. The structure is modelled in space using the finite element method.

\section{ANALYSIS OF BUILDING STRUCTURES WITH OR WITHOUT UNDERGROUND STOREY}

\section{A. Analyzed Cases}

Taking into account conventional buildings in our country, the 5 storeys reinforced concrete structures are considered in the analysis [6]. To study the effect of underground storey to the seismic behaviour of reinforced concrete buildings, three types of structures are considered: Type 1-FRAME structure, Type 2-MIX structure and Type 3-BOX structure. Each type of structure will be modelled in three different ways: First model of each type is the structure without underground storey and it will be named - Model 1a, Model 2a and Model 3a respectively. Second model of each type is the structure with surrounding RC walls of underground storey and it will be named - Model 1b, Model 2b and Model 3b respectively. 
Third model of each type is the structure with underground storey but the surrounding walls are not connected with the structure and it will be named - Model 1c, Model 2c and Model 3c respectively. Schematically, the analyzed models for three types of structures are presented in Table 1:

TABLE I: THE ANALYZED MODELS FOR THREE TYPES OF STRUCTURES

\begin{tabular}{||c|c|c|c||}
\hline \multirow{2}{*}{ Structure TYPE } & \multicolumn{3}{|c||}{ Analyzed Models } \\
\cline { 2 - 4 } & $\begin{array}{c}\text { No } \\
\text { Underground } \\
\text { Storey }\end{array}$ & $\begin{array}{c}\text { Underground Stiff } \\
\text { Storey }\end{array}$ & $\begin{array}{c}\text { Underground } \\
\text { Flexible Storey }\end{array}$ \\
\hline FRAME & Model 1a & Model 1b & Model 1c \\
\hline MIX & Model 2a & Model 2b & Model 2c \\
\hline BOX & Model 3a & Model 3b & Model 3c \\
\hline
\end{tabular}

\section{B. Structural Elements Geometry}

Geometry and physical and mechanical properties of materials are the same for all the types of structures, FRAME, MIX, and BOX structure.

Storey height: First Storey $\mathrm{H} 1=5.15 \mathrm{~m}$, other storeys $\mathrm{Hk}=3.15 \mathrm{~m}$; Concrete Class: C25/30

Building elements dimensions: $\mathrm{bt}=30 \mathrm{~cm}$

Slab thickness: $\mathrm{hs}=15 \mathrm{~cm}$, Beams dimensions: $\mathrm{ht}=60 \mathrm{~cm}$,

Columns: peripheral columns $\mathrm{bk}=40 \mathrm{~cm}, \mathrm{hk}=60 \mathrm{~cm}$, central columns bk $=60 \mathrm{~cm}, \mathrm{hk}=60 \mathrm{~cm}$

Reinforced concrete shear walls: $\mathrm{tm}=20 \mathrm{~cm}$

Structure geometry is shown in Figures 1 to 4 .
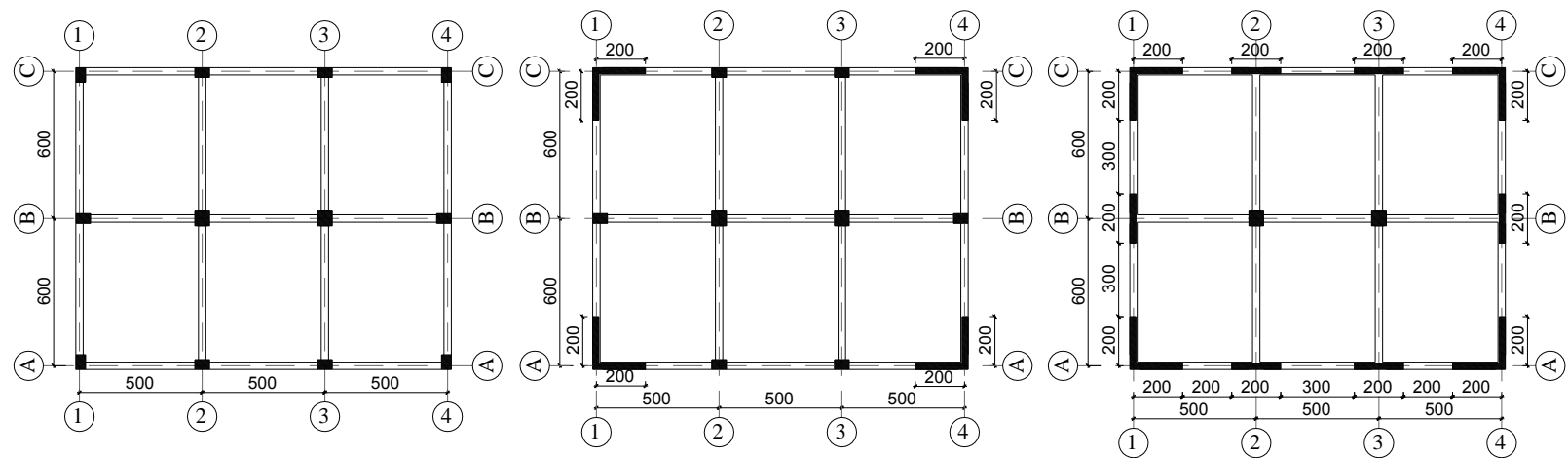

Fig. 1: The structural plan of three types of structures: a) FRAME; b) MIX; c) BOX
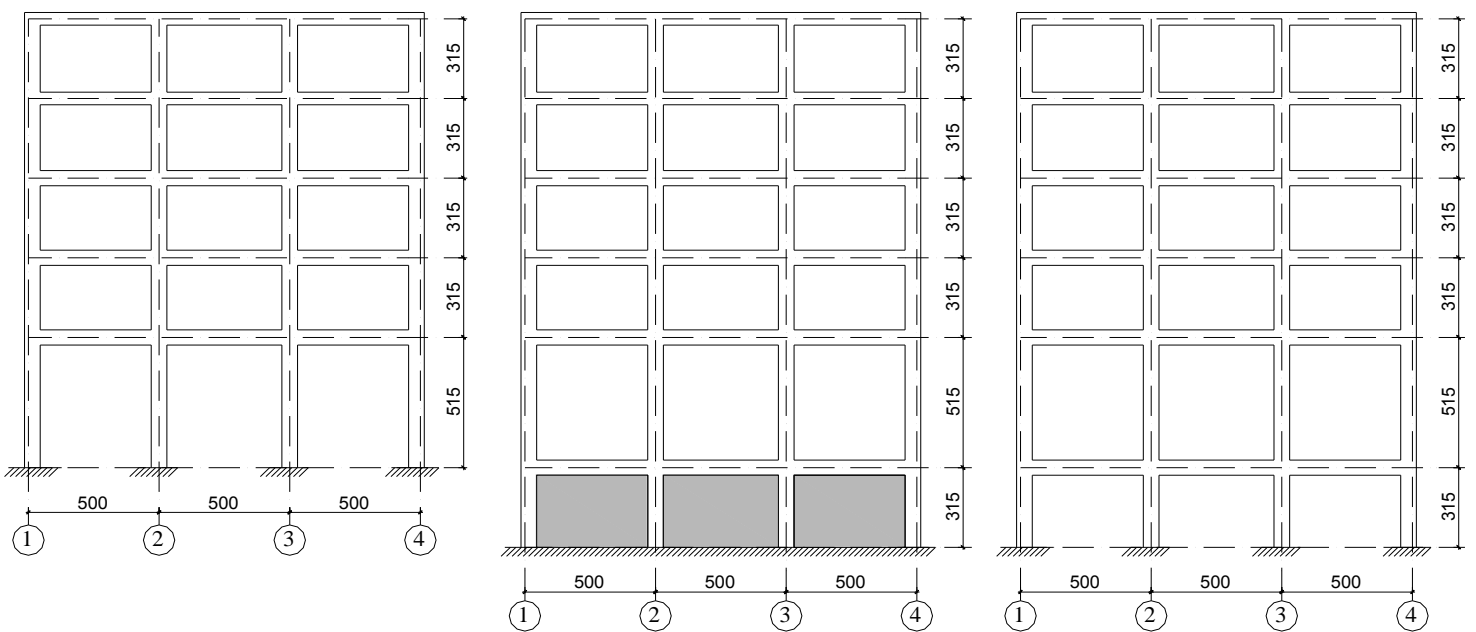

Fig. 2: The structural view of FRAME structures: a) Model 1a; b) Model 1b; c) Model 1c 

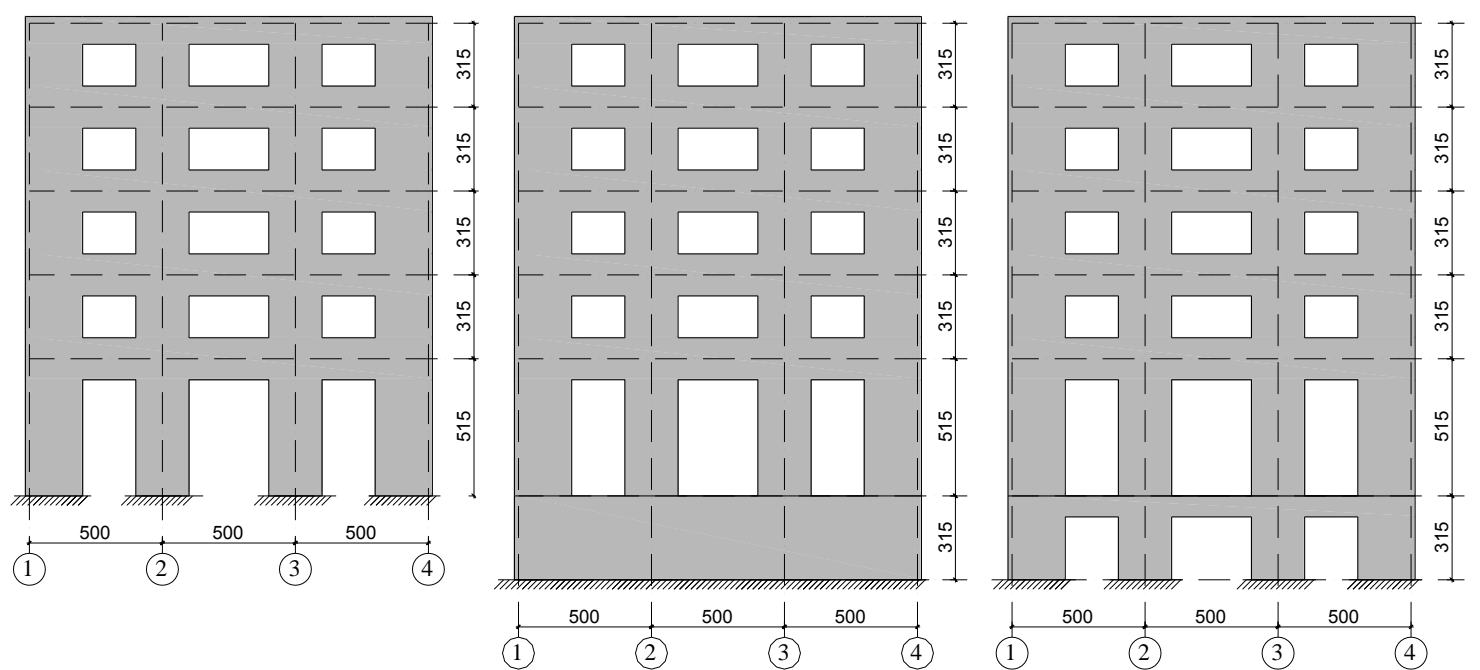

Fig. 3: The structural view of MIX structures: a) Model 2a; b) Model 2b; c) Model 2c
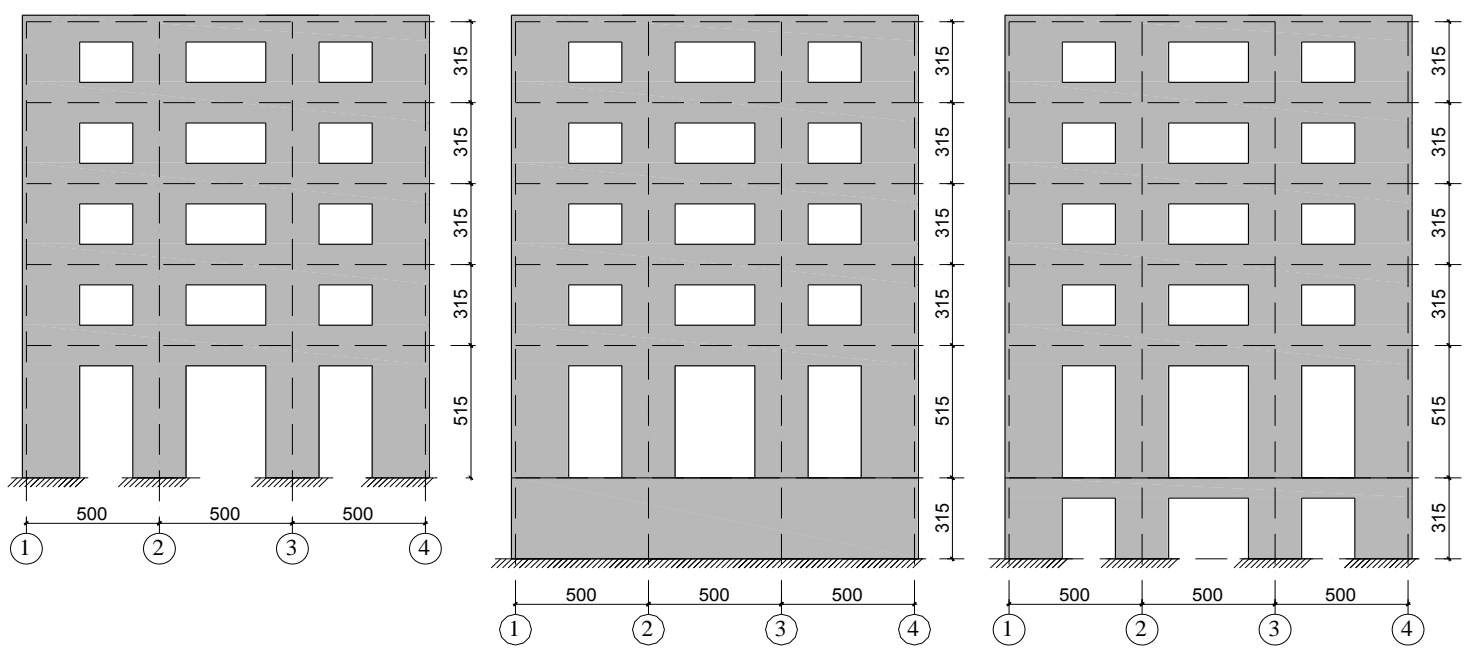

Fig. 4: The structural view of BOX structures: a) Model 3a; b) Model 3b; c) Model 3c

\section{Applied loads}

To calculate the dynamic parameters and to perform the seismic analyze, the loads applied to the structure are: dead loads $\mathrm{g}=300 \mathrm{daN} / \mathrm{m} 2$, live loads $\mathrm{p}=200 \mathrm{daN} / \mathrm{m} 2$ and earthquake loads [4]. The earthquake load is applied through real earthquake accelerogram scaled for the chosen ground conditions, with ground acceleration $A m a x=0.25 \mathrm{~g}$. The applied accelerogram is that of El Centro earthquake with peak ground acceleration $\mathrm{PGA}=0,349 \mathrm{~g}$ [1], scaled with scale factor $\mathrm{S}=(0.25 / 0,349) \times 10-3=0.716 \times 10-3$. These excitations are induced in both, $\mathrm{X}$ and $\mathrm{Y}$, directions.

\section{Structure modeling}

The time history analysis is performed by SAP2000 software program [7]. The structure is modelled in space using the finite element method. Beams and columns are modelled as Frame elements, slabs and shear walls are modelled as Shell elements.

\section{E. Analysis results}

\section{1) Dynamic response parameters}

The values of the first three periods of the analyzed models are given in Tables 2 to 4 :

TABLE II: VIBRATION PERIODS OF THREE MODELS OF FRAME STRUCTURE

\begin{tabular}{||c|c|c|c||}
\hline \multirow{2}{*}{$\begin{array}{c}\text { Mode } \\
\text { number }\end{array}$} & \multicolumn{3}{|c|}{ Period } \\
\cline { 2 - 4 } & Model 1a & Model 1b & Model 1c \\
\hline 1 & 1 & 1.05 & 1.21 \\
\hline 2 & 0.9 & 0.94 & 1.07 \\
\hline 3 & 0.79 & 0.81 & 0.94 \\
\hline
\end{tabular}

TABLE III: VIBRATION PERIODS OF THREE MODELS OF MIX STRUCTURE

\begin{tabular}{|c|c|c|c|}
\hline \hline \multirow{2}{*}{$\begin{array}{c}\text { Mode } \\
\text { number }\end{array}$} & \multicolumn{3}{|c|}{ Period } \\
\cline { 2 - 4 } & Model 2a & Model 2b & Model 2c \\
\hline 1 & 0.57 & 0.61 & 0.71 \\
\hline 2 & 0.51 & 0.55 & 0.63 \\
\hline 3 & 0.33 & 0.36 & 0.42 \\
\hline
\end{tabular}


TABLE IV: VIBRATION PERIODS OF THREE MODELS OF BOX STRUCTURE

\begin{tabular}{||c|c|c|c||}
\hline \multirow{2}{*}{$\begin{array}{c}\text { Mode } \\
\text { number }\end{array}$} & \multicolumn{3}{|c|}{ Period } \\
\cline { 2 - 4 } & Model 3a & Model 3b & Model 3c \\
\hline 1 & 0.21 & 0.24 & 0.27 \\
\hline 2 & 0.20 & 0.23 & 0.26 \\
\hline 3 & 0.11 & 0.13 & 0.15 \\
\hline
\end{tabular}

It can be noted that for all three models, the first mode shape is translational in $\mathrm{Y}$ direction, the second mode shape is translational in $\mathrm{X}$ direction, and the third mode shape is torsional around $\mathrm{Z}$ direction. As it was expected the structure models with underground storey have longer periods of vibration compared with structures without underground

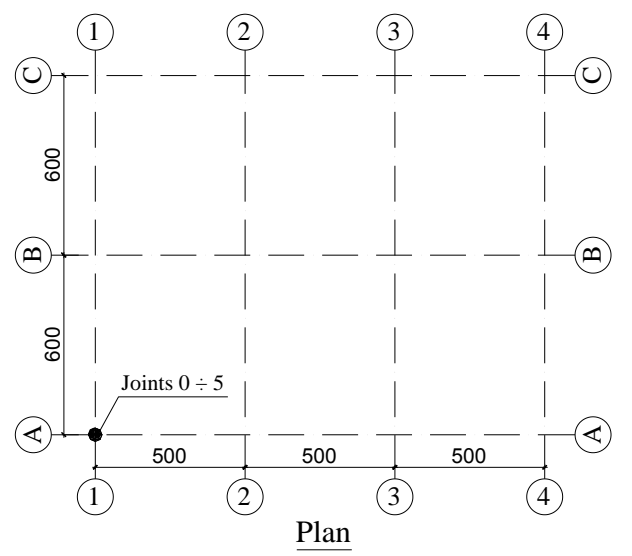

storey. This will influence the general seismic behaviour of structures.

\section{2) Seismic response results}

Seismic response of all models of the structures, are numerically given in Tables 5 to 13 . The selected parameters are the maximum values in $\mathrm{X}$ and $\mathrm{Y}$ directions of accelerations; storey deformations (storey drifts); shear forces on the columns of first and top storey; bending moments on beams of the first and top storey; base shear force. Also vertical stresses S22 and horizontal stresses S11 of the shear walls of the first storey are presented.

The position of chosen joints used for introducing the seismic response results are schematically shown in Figure 5.

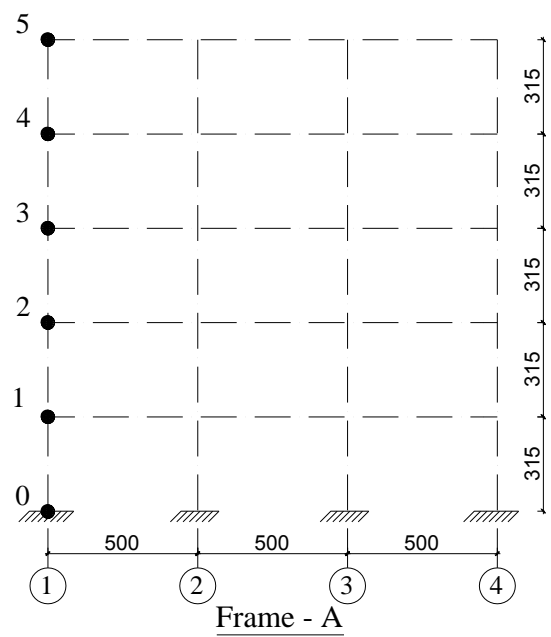

Fig. 5: Position of chosen joints for introducing seismic response results

The position of chosen elements used for introducing the seismic response results are schematically shown in Figure 6.
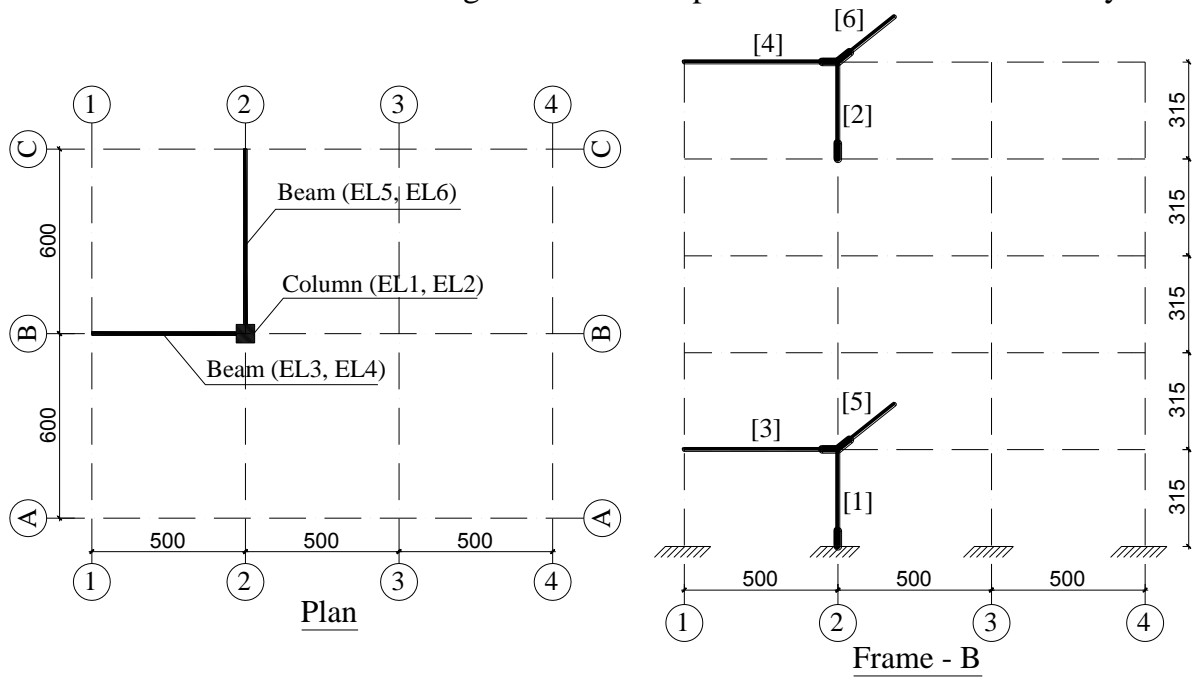

Fig. 6: Position of chosen elements for introducing seismic response results

The position of chosen shear walls used for introducing the seismic response results are schematically shown in Figure 7. 

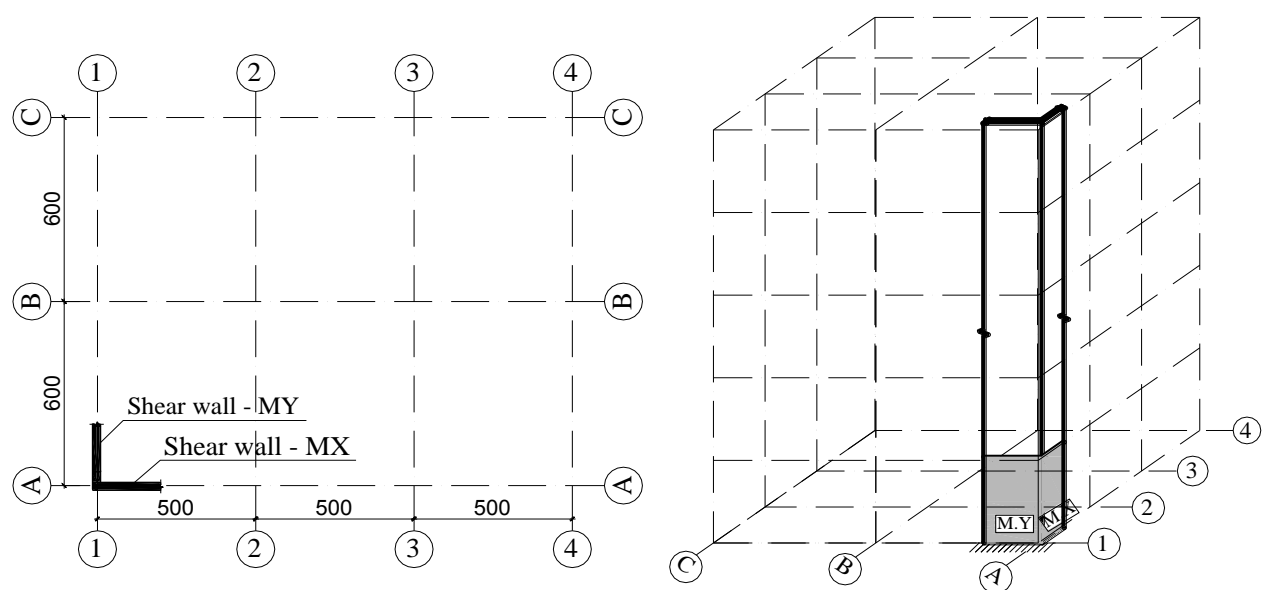

Fig. 7: Position of chosen shear walls for introducing seismic response results

All the interesting results from the dynamic analysis of three Types of structure are presented in Tables 5 to 13 , below:

TABLE V: ACCELERATION RESULTS (M/S2) OF FRAME STRUCTURE

\begin{tabular}{|c|c|c|c|c|c|c|c|c|c|c||}
\hline \multirow{2}{*}{ Location } & \multicolumn{2}{|c|}{ Model 1a } & \multicolumn{2}{|c|}{ Model 1b } & \multicolumn{2}{|c|}{ Model 1c } & \multicolumn{2}{|c|}{ M 1b/M 1a Ratio } & \multicolumn{2}{c|}{ M 1c/M 1a } \\
Ratio
\end{tabular}

TABLE VI: ACCELERATION RESULTS (M/S2) OF MIX STRUCTURE

\begin{tabular}{|c|c|c|c|c|c|c|c|c|c|c|}
\hline \multirow{2}{*}{ Location } & \multicolumn{2}{|c|}{ Model 2a } & \multicolumn{2}{|c|}{ Model 2b } & \multicolumn{2}{|c|}{ Model 2c } & \multicolumn{2}{|c|}{$\begin{array}{c}\text { M 2b/M 2a } \\
\text { Ratio }\end{array}$} & \multicolumn{2}{|c|}{$\begin{array}{c}\text { M 2c/M 2a } \\
\text { Ratio }\end{array}$} \\
\hline & $X$ & $\mathrm{Y}$ & $\mathrm{X}$ & Y & $X$ & $\mathrm{Y}$ & $\mathrm{X}$ & $\mathrm{Y}$ & $\mathrm{X}$ & $\mathrm{Y}$ \\
\hline First-storey, on Ground (joint 0) & 2.29 & 2.29 & 2.32 & 2.33 & 2.37 & 2.05 & 1.01 & 1.02 & 1.03 & 0.90 \\
\hline First-storey, on top (joint 1) & 2.95 & 3.01 & 3.30 & 2.88 & 3.01 & 2.18 & 1.12 & 0.96 & 1.02 & 0.72 \\
\hline Roof (joint 5) & 8.26 & 8.71 & 10.06 & 9.88 & 9.51 & 6.6 & 1.22 & 1.13 & 1.15 & 0.76 \\
\hline
\end{tabular}

TABLE VII: ACCELERATION RESULTS (M/S2) OF BOX STRUCTURE

\begin{tabular}{|c|c|c|c|c|c|c|c|c|c|c|}
\hline \multirow{2}{*}{ Location } & \multicolumn{2}{|c|}{ Model 3a } & \multicolumn{2}{|c|}{ Model 3b } & \multicolumn{2}{|c|}{ Model 3c } & \multicolumn{2}{|c|}{$\begin{array}{c}\text { M 3b/M 3a } \\
\text { Ratio }\end{array}$} & \multicolumn{2}{|c|}{$\begin{array}{c}\text { M 3c/M 3a } \\
\text { Ratio }\end{array}$} \\
\hline & $\mathrm{X}$ & $\mathrm{Y}$ & $\mathrm{X}$ & $\mathrm{Y}$ & $\mathrm{X}$ & $\mathrm{Y}$ & $\mathrm{X}$ & $\mathrm{Y}$ & $\mathrm{X}$ & $\mathrm{Y}$ \\
\hline First-storey, on Ground (joint 0) & 2.29 & 2.29 & 2.4 & 2.43 & 2.24 & 2.36 & 1.05 & 1.06 & 0.98 & 1.03 \\
\hline First-storey, on top (joint 1) & 2.97 & 2.56 & 3.71 & 3.23 & 3.53 & 3.61 & 1.25 & 1.26 & 1.19 & 1.41 \\
\hline Roof (joint 5) & 5.73 & 5.78 & 6.06 & 6.48 & 5.92 & 6.17 & 1.06 & 1.12 & 1.03 & 1.07 \\
\hline
\end{tabular}

TABLE VIII: STOREY DEFORMATION (DRIFTS) RESULTS (CM) OF FRAME STRUCTURE

\begin{tabular}{|c|c|c|c|c|c|c|c|c|c|c|}
\hline \multirow{2}{*}{ Storey } & \multicolumn{2}{|c|}{ Model 1a } & \multicolumn{2}{|c|}{ Model 1b } & \multicolumn{2}{|c|}{ Model 1c } & \multicolumn{2}{|c|}{$\begin{array}{l}\text { M 1b/M 1a } \\
\text { Ratio }\end{array}$} & \multicolumn{2}{|c|}{$\begin{array}{l}\text { M 1c/M 1a } \\
\text { Ratio }\end{array}$} \\
\hline & $X$ & $\mathrm{Y}$ & $X$ & $\mathrm{Y}$ & $X$ & $\mathrm{Y}$ & $X$ & $\mathrm{Y}$ & $\mathrm{X}$ & $\mathrm{Y}$ \\
\hline Storey -1 & 0 & 0 & 0.04 & 0.1 & 1.21 & 1.21 & NA & NA & NA & NA \\
\hline Storey 1 & 3.95 & 4.65 & 4.63 & 4.77 & 4.58 & 4.35 & 1.17 & 1.03 & 1.16 & 0.94 \\
\hline Storey 2 & 1.97 & 2.52 & 1.94 & 2.26 & 1.83 & 1.69 & 0.98 & 0.90 & 0.93 & 0.67 \\
\hline Storey 3 & 1.56 & 1.96 & 1.55 & 1.68 & 1.44 & 1.32 & 0.99 & 0.86 & 0.92 & 0.67 \\
\hline Storey 4 & 1.14 & 1.37 & 1.16 & 1.16 & 1.05 & 0.91 & 1.02 & 0.85 & 0.92 & 0.66 \\
\hline Storey 5 & 0.66 & 0.8 & 0.68 & 0.88 & 0.59 & 0.52 & 1.03 & 1.10 & 0.89 & 0.65 \\
\hline
\end{tabular}


TABLE IX: STOREY DEFORMATION (DRIFTS) RESULTS (CM) OF MIX STRUCTURE

\begin{tabular}{|c|c|c|c|c|c|c|c|c|c|c|}
\hline \multirow{2}{*}{ Storey } & \multicolumn{2}{|c|}{ Model 1a } & \multicolumn{2}{|c|}{ Model 1b } & \multicolumn{2}{|c|}{ Model 1c } & \multicolumn{2}{|c|}{$\begin{array}{c}\text { M 2b/M 2a } \\
\text { Ratio }\end{array}$} & \multicolumn{2}{|c|}{$\begin{array}{c}\text { M 2c/M 2a } \\
\text { Ratio }\end{array}$} \\
\hline & $X$ & $\mathrm{Y}$ & $X$ & $\mathrm{Y}$ & $X$ & $\mathrm{Y}$ & $\mathrm{X}$ & Y & $\mathrm{X}$ & $\mathrm{Y}$ \\
\hline Storey -1 & 0 & 0 & 0.09 & 0.09 & 0.49 & 0.46 & NA & NA & NA & NA \\
\hline Storey 1 & 1.07 & 1.36 & 1.56 & 1.62 & 1.93 & 1.83 & 1.46 & 1.19 & 1.80 & 1.35 \\
\hline Storey 2 & 1.06 & 1.41 & 1.31 & 1.45 & 1.3 & 1.28 & 1.24 & 1.03 & 1.23 & 0.91 \\
\hline Storey 3 & 1.11 & 1.53 & 1.3 & 1.5 & 1.26 & 1.23 & 1.17 & 0.98 & 1.14 & 0.80 \\
\hline Storey 4 & 1.03 & 1.47 & 1.18 & 1.43 & 1.12 & 1.14 & 1.15 & 0.97 & 1.09 & 0.78 \\
\hline Storey 5 & 0.91 & 1.34 & 1.03 & 1.29 & 0.97 & 1.03 & 1.13 & 0.96 & 1.07 & 0.77 \\
\hline
\end{tabular}

TABLE X: STOREY DEFORMATION (DRIFTS) RESULTS (CM) OF BOX STRUCTURE

\begin{tabular}{|c|c|c|c|c|c|c|c|c|c|c|}
\hline \multirow{2}{*}{ Storey } & \multicolumn{2}{|c|}{ Model 1a } & \multicolumn{2}{|c|}{ Model 1b } & \multicolumn{2}{|c|}{ Model 1c } & \multicolumn{2}{|c|}{$\begin{array}{c}\text { M 3b/M 3a } \\
\text { Ratio }\end{array}$} & \multicolumn{2}{|c|}{$\begin{array}{c}\text { M 3c/M 3a } \\
\text { Ratio }\end{array}$} \\
\hline & $X$ & $\mathrm{Y}$ & $\mathrm{X}$ & $\mathrm{Y}$ & $X$ & $\mathrm{Y}$ & $X$ & $\mathrm{Y}$ & $X$ & $\mathrm{Y}$ \\
\hline Storey -1 & 0 & 0 & 0.07 & 0.07 & 0.16 & 0.14 & NA & NA & NA & NA \\
\hline Storey 1 & 0.3 & 0.23 & 0.42 & 0.33 & 0.48 & 0.39 & 1.40 & 1.43 & 1.60 & 1.70 \\
\hline Storey 2 & 0.12 & 0.12 & 0.15 & 0.15 & 0.15 & 0.17 & 1.25 & 1.25 & 1.25 & 1.42 \\
\hline Storey 3 & 0.1 & 0.11 & 0.12 & 0.13 & 0.13 & 0.15 & 1.20 & 1.18 & 1.30 & 1.36 \\
\hline Storey 4 & 0.08 & 0.09 & 0.1 & 0.12 & 0.1 & 0.14 & 1.25 & 1.33 & 1.25 & 1.56 \\
\hline Storey 5 & 0.06 & 0.07 & 0.08 & 0.09 & 0.07 & 0.08 & 1.33 & 1.29 & 1.17 & 1.14 \\
\hline
\end{tabular}

TABLE XI: FORCES RESPONSE RESULTS OF FRAME STRUCTURE

\begin{tabular}{|c|c|c|c|c|c|c|c|c|c|c|c|}
\hline \multirow{2}{*}{ Parameter } & \multirow{2}{*}{ Location } & \multicolumn{2}{|c|}{ Model 1a } & \multicolumn{2}{|c|}{ Model 1b } & \multicolumn{2}{|c|}{ Model 1c } & \multicolumn{2}{|c|}{$\begin{array}{l}\text { M 1b/M 1a } \\
\text { Ratio }\end{array}$} & \multicolumn{2}{|c|}{$\begin{array}{l}\text { M 1c/M 1a } \\
\text { Ratio } \\
\end{array}$} \\
\hline & & $X$ & Y & $X$ & $\mathrm{Y}$ & $X$ & $\mathrm{Y}$ & $X$ & $\mathrm{Y}$ & $X$ & $\mathrm{Y}$ \\
\hline \multirow{3}{*}{$\begin{array}{c}\text { Column shear force } \\
(\mathrm{kN})\end{array}$} & Underground storey & 0 & 0 & 358 & 393 & 598 & 561 & NA & NA & NA & NA \\
\hline & $1^{\text {st }}$ storey (EL1) & 750 & 820 & 725 & 680 & 620 & 530 & 0.97 & 0.83 & 0.83 & 0.65 \\
\hline & Roof (EL2) & 195 & 185 & 200 & 215 & 181 & 126 & 1.03 & 1.16 & 0.93 & 0.68 \\
\hline \multirow{2}{*}{ Beam moment $(\mathrm{kNm})$} & $1^{\text {st }}$ storey (EL3-EL5) & 1056 & 1112 & 1069 & 865 & 982 & 810 & 1.01 & 0.78 & 0.93 & 0.73 \\
\hline & Roof (EL4-EL6) & 159 & 183 & 212 & 207 & 139 & 122 & 1.33 & 1.13 & 0.87 & 0.67 \\
\hline Base shear force $(\mathrm{kN})$ & Storey 0 or -1 & 5530 & 5414 & 5780 & 4870 & 4584 & 3850 & 1.05 & 0.90 & 0.83 & 0.71 \\
\hline
\end{tabular}

TABLE XII: FORCES RESPONSE RESULTS OF MIX STRUCTURE

\begin{tabular}{|c|c|c|c|c|c|c|c|c|c|c|c|}
\hline \multirow{2}{*}{ Parameter } & \multirow{2}{*}{ Location } & \multicolumn{2}{|c|}{ Model 2a } & \multicolumn{2}{|c|}{ Model 2b } & \multicolumn{2}{|c|}{ Model 2c } & \multicolumn{2}{|c|}{$\begin{array}{l}\text { M 2b/M 2a } \\
\text { Ratio }\end{array}$} & \multicolumn{2}{|c|}{$\begin{array}{l}\text { M 2c/M 2a } \\
\text { Ratio }\end{array}$} \\
\hline & & $X$ & $\mathrm{Y}$ & $\mathrm{X}$ & $\mathrm{Y}$ & $X$ & $\mathrm{Y}$ & $\mathrm{X}$ & $\mathrm{Y}$ & $\mathrm{X}$ & $\mathrm{Y}$ \\
\hline \multirow{3}{*}{$\begin{array}{l}\text { Column shear force } \\
(\mathrm{kN})\end{array}$} & Underground storey & 0 & 0 & 85 & 93 & 251 & 208 & NA & NA & NA & NA \\
\hline & $1^{\text {st }}$ storey (EL1) & 157 & 177 & 200 & 178 & 220 & 182 & 1.27 & 1.01 & 1.40 & 1.03 \\
\hline & Roof (EL2) & 367 & 473 & 415 & 453 & 378 & 353 & 1.13 & 0.96 & 1.03 & 0.75 \\
\hline \multirow{2}{*}{ Beam moment $(\mathrm{kNm})$} & $1^{\text {st }}$ storey (EL3-EL5) & 410 & 467 & 518 & 487 & 537 & 458 & 1.26 & 1.04 & 1.31 & 0.98 \\
\hline & Roof (EL4-EL6) & 265 & 368 & 295 & 353 & 270 & 276 & 1.11 & 0.96 & 1.02 & 0.75 \\
\hline Base shear force $(\mathrm{kN})$ & Storey 0 or -1 & 9843 & 9027 & 9495 & 8227 & 8243 & 6787 & 0.96 & 0.91 & 0.84 & 0.75 \\
\hline \multirow{2}{*}{$\begin{array}{c}\text { Shear wall stresses } \\
(\mathrm{daN} / \mathrm{cm} 2)\end{array}$} & Vertical & 380 & 390 & 300 & 260 & 200 & 190 & 0.79 & 0.67 & 0.53 & 0.49 \\
\hline & Horizontal & 100 & 110 & 90 & 88 & 32 & 31 & 0.90 & 0.80 & 0.32 & 0.28 \\
\hline
\end{tabular}


TABLE XIII: FORCES RESPONSE RESULTS OF BOX STRUCTURE

\begin{tabular}{|c|c|c|c|c|c|c|c|c|c|c|c|}
\hline \multirow{2}{*}{ Parameter } & \multirow{2}{*}{ Location } & \multicolumn{2}{|c|}{ Model 3a } & \multicolumn{2}{|c|}{ Model 3b } & \multicolumn{2}{|c|}{ Model 3c } & \multicolumn{2}{|c|}{$\begin{array}{c}\text { M 3b/M 3a } \\
\text { Ratio }\end{array}$} & \multicolumn{2}{|c|}{$\begin{array}{l}\text { M 3c/M 3a } \\
\text { Ratio } \\
\end{array}$} \\
\hline & & $\mathrm{X}$ & $\mathrm{Y}$ & $\mathrm{X}$ & $\mathrm{X}$ & $\mathrm{X}$ & $\mathrm{Y}$ & $\mathrm{X}$ & $\mathrm{Y}$ & $\mathrm{X}$ & $\mathrm{Y}$ \\
\hline \multirow{3}{*}{ Column shear force $(\mathrm{kN})$} & Underground storey & 0 & 0 & 3 & 17 & 68 & 56 & NA & NA & NA & NA \\
\hline & $1^{\text {st }}$ storey (EL1) & 57 & 37 & 56 & 32 & 65 & 39 & 0.98 & 0.86 & 1.14 & 1.05 \\
\hline & Roof (EL2) & 11 & 10 & 13 & 13 & 15 & 15 & 1.18 & 1.30 & 1.36 & 1.50 \\
\hline \multirow{2}{*}{ Beam moment (kNm) } & $1^{\text {st }}$ storey (EL3-EL5) & 55 & 38 & 64 & 45 & 67 & 52 & 1.16 & 1.18 & 1.22 & 1.37 \\
\hline & Roof (EL4-EL6) & 4 & 8 & 3 & 11 & 3 & 12 & 0.75 & 1.38 & 0.75 & 1.50 \\
\hline Base shear force $(\mathrm{kN})$ & Storey 0 or -1 & 7972 & 7686 & 9122 & 8678 & 9254 & 9362 & 1.14 & 1.13 & 1.16 & 1.22 \\
\hline \multirow{2}{*}{$\begin{array}{c}\text { Shear wall stresses } \\
(\mathrm{daN} / \mathrm{cm} 2)\end{array}$} & Vertical & 100 & 65 & 50 & 41 & 55 & 35 & 0.50 & 0.63 & 0.55 & 0.54 \\
\hline & Horizontal & 25 & 18 & 33 & 25 & 45 & 36 & 1.32 & 1.39 & 1.80 & 2.00 \\
\hline
\end{tabular}

Graphical Presentation of some chosen parameters, are given in Figures 8 to 11 .

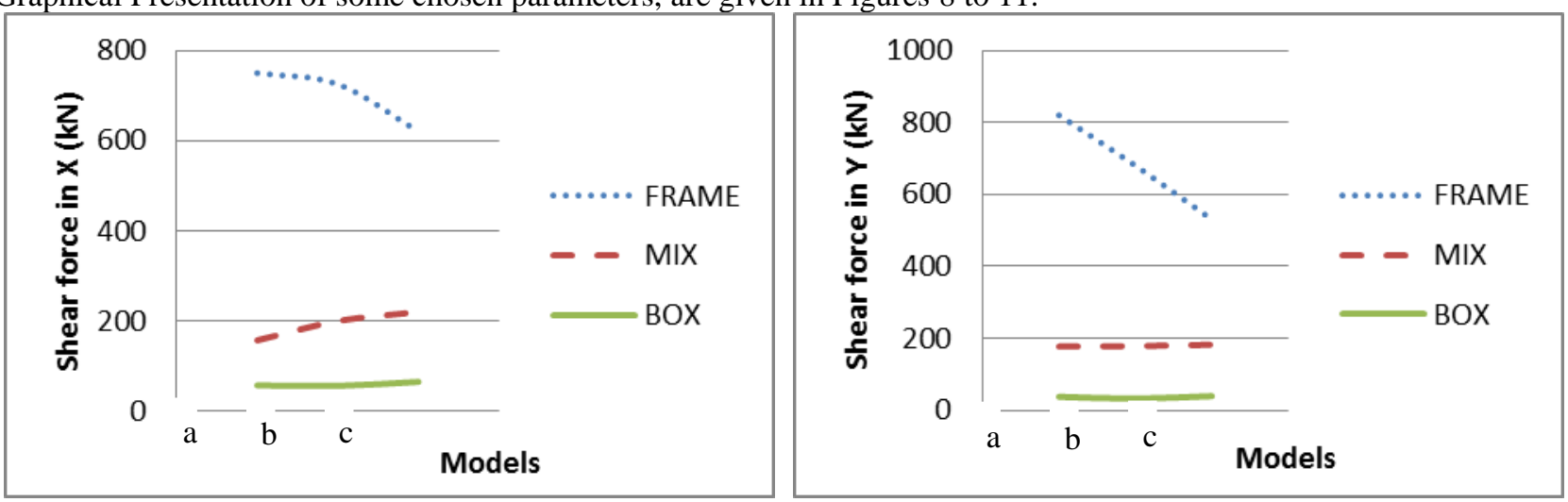

Fig. 8: Shear Force on First Storey Column: a) in X direction; b) in Y direction

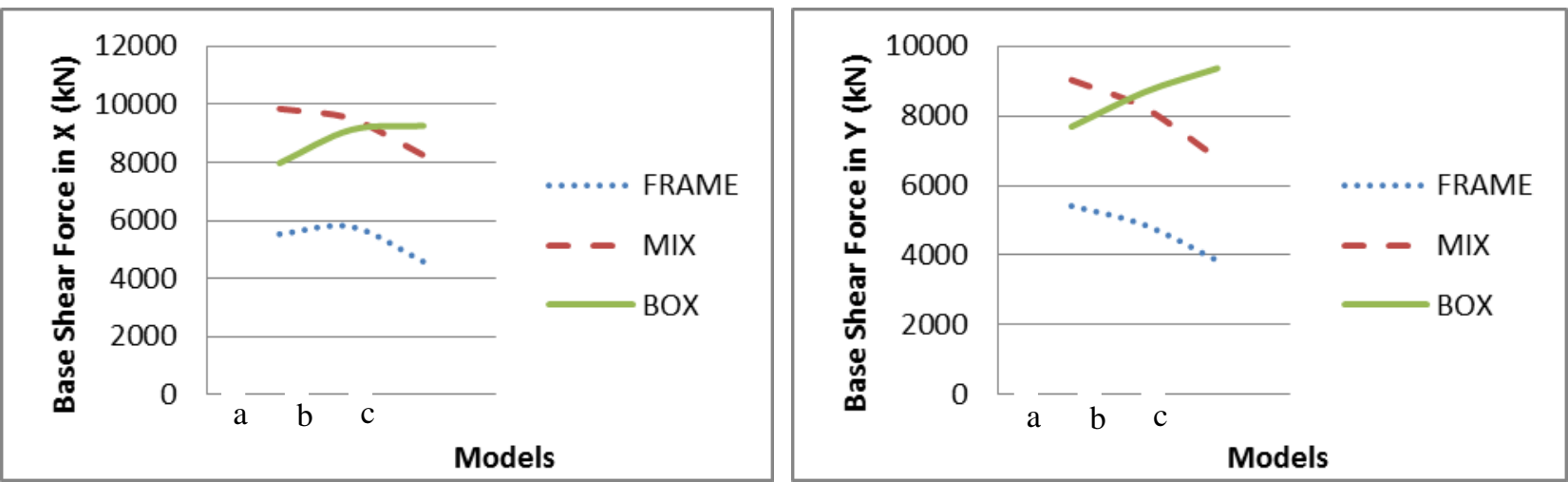

Fig. 9: Base Shear Force: a) in X direction; b) in Y direction
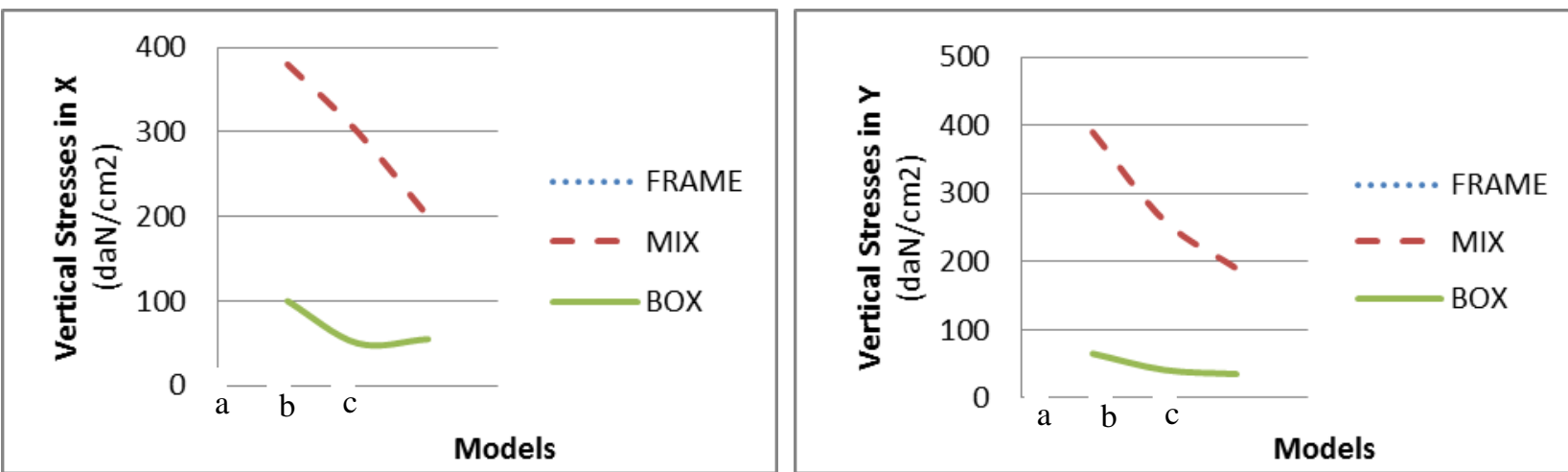

Fig. 10: Vertical Stresses on First Storey Shear Wall: a) Earthquake in X; b) Earthquake in Y 

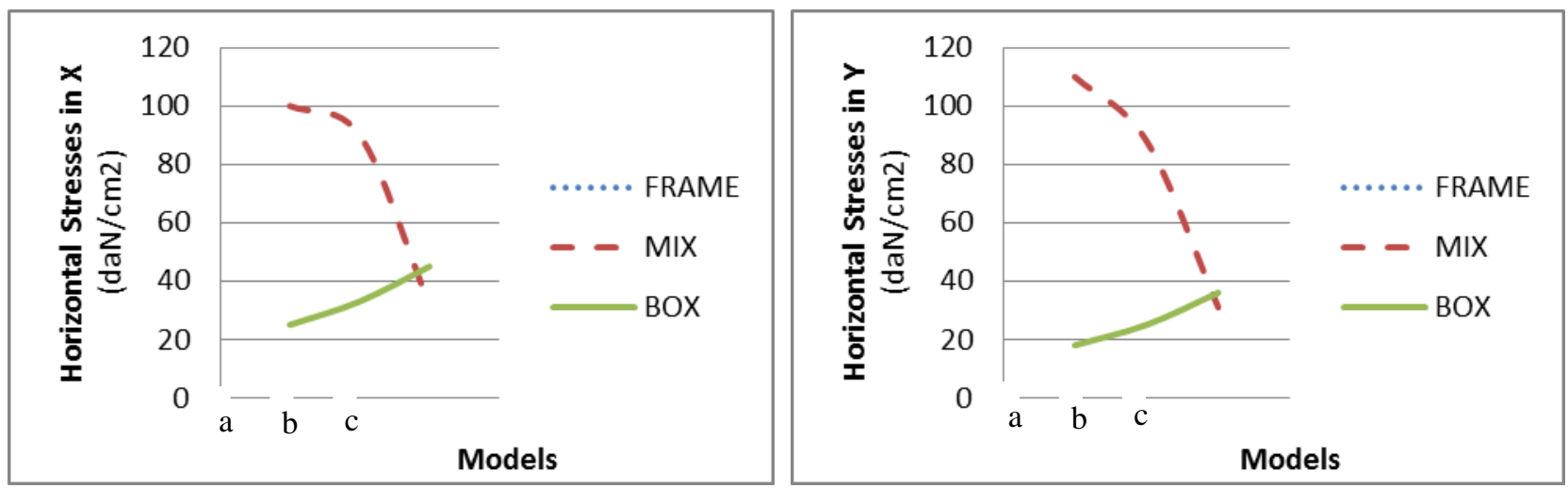

Fig. 11: Horizontal Stresses on First Storey Shear Wall: a) Earthquake in X; b) Earthquake in Y

\section{CONCLUSION}

In this study, based on the above analyses and results we can conclude that:

Adding the underground storey to the building structure will lengthen the vibration periods, which in most cases can reduce the seismic forces acting to the structure. The accelerations of structures are influenced from the underground storey, but this influence is different for different type of structures. The storey deformations are reduced in case of FRAME structure, but not in MIX and BOX structure.

The shear forces in the columns of the first storey and the base shear force of FRAME structure are reduced around $20 \%$ from the presence of underground storey. In case of MIX structure, the presence of underground storey is reducing the stresses in shear walls around $30 \%$.

The additional underground storey has positive influence on internal member forces in case of flexible structures especially when ground floor requirements are difficult to achieve. The positive influence is increased if the surrounding walls of underground storey are not touched on the structure elements. Very stiff structures, like in case of BOX type, have the vibration periods in acceleration sensitive zone of the response spectrum. Thus, the influence of underground storey on these structures is not beneficial and may be negative.

\section{REFERENCES}

[1] Chopra, A. K., "Dynamics of Structures: Theory and Application to Earthquake Engineering”, Prentice-Hall, New Jersey, 1995.

[2] Chopra, A. K., "Dynamics of Structures: Theory and Application to Earthquake Engineering", 2nd Ed, Pearson Prentice Hall, Upper Saddle River, New Jersey, 2007

[3] Clough, R.W., Penzien, J. "Dynamics of Structures", McGraw-Hill, New York, 1993

[4] Eurocode, EN 1998, "Design of Structures for earthquake Resistance", 2004

[5] Khashaee P., Mohraz B., Sadek F., Lew H. S., Gross J.L., "Distribution of Earthquake Input Energy in Structures", NISTIR 6303, National Institute of Technology and Standards, USA 2003

[6] Marnetto R., Massa L., Vailati M." Progeto Sismico di Strutture Nuove in Cemento Armato", Edizioni Kappa, Roma, Italy, 2004

[7] SAP2000®, Integrated Finite Element Analysis and Design of Structures, analysis Reference, Vol. 1\&2, Computer and Structures, Inc, Berkeley, California, USA, 2000 